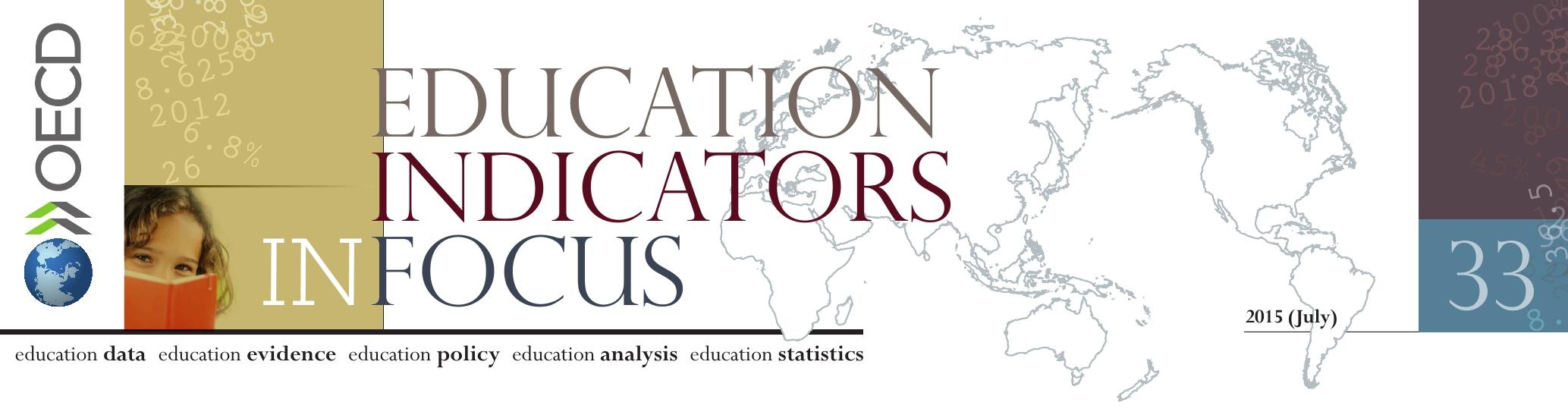

\title{
Focus on vocational education and training (VET) programmes
}

- In 2012, in more than one-third of OECD countries, over half of all upper secondary students participated in pre-vocational or vocational programmes but less than $30 \%$ of those students were exposed to work-based learning.

- Countries with well-established and high-quality vocational and apprenticeship programmes have improved youth employment opportunities. However, in many OECD countries, the share of young people who are neither employed, nor in education or training (NEET) is still higher for graduates from upper secondary VET than from upper secondary general programmes.

- Students who enter vocational programmes are less likely to graduate than those who are enrolled in general programmes. Moreover, they are nearly five times less likely to enrol in further education than graduates from general secondary schools with similar proficiency in literacy.

Vocational education and training (VET) can play a central role in preparing young people for work, developing adults' skills and responding to the labour-market needs of the economy. However, VET has been neglected in the past and marginalised in policy discussions, often overshadowed by the increasing emphasis on general academic education. Nevertheless, more recently, an increasing number of countries are recognising that high quality vocational education and training have a major contribution to make to economic competitiveness.

Figure 1. Proportion of students enrolled in upper secondary VET programmes (2012)

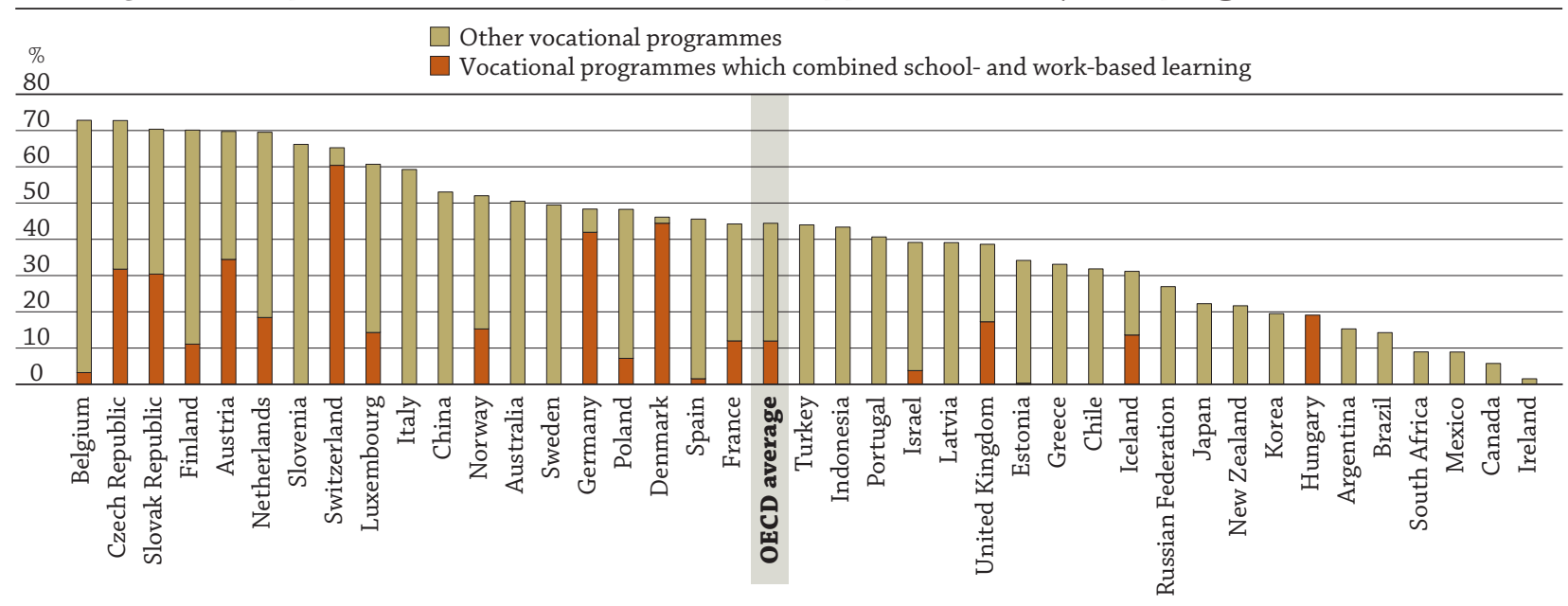

Countries are ranked in descending order of the proportion of students enrolled in upper secondary vocational programmes.

Source: OECD (2014), Education at a Glance 2014: OECD Indicators, Indicator C1 (http://dx.doi.org/10.1787/eag-2014-en).

On average, 44\% of all upper secondary students enrol in vocational programmes. However, the importance of VET systems varies widely across countries. In some, VET plays a central role in the initial education of young people whereas in other systems, most students go into general education. Globally, in more than one-third of the OECD countries in 2012, the percentage of students who participated in pre-vocational or vocational programmes exceeded $50 \%$ of all students enrolled in upper secondary education - and this proportion was at least $70 \%$ in Austria, Belgium, the Czech Republic, Finland, the Netherlands and the Slovak Republic (Figure 1). 
Vocational education and training is mainly designed to help participants acquire the practical skills, know-how and understanding necessary for employment in a particular occupation or trade, or class of occupations or trades.

In combined school- and work-based programmes, less than $75 \%$ of the curriculum is presented in the school environment or through distance education. These programmes include apprenticeship programmes that involve concurrent school-based and work-based training, and programmes that involve alternating periods of attendance at educational institutions and participation in work-based training.

Students who enter vocational programmes are less likely to graduate than those who are enrolled in general programmes: in 2012 , only $64 \%$ of students completed their vocational programme within the time theoretically allowed. However, two years after the stipulated time, the proportion graduating has increased by 15 percentage points. On average, completion rates for general upper secondary programmes are 13 percentage points higher than for vocational ones, but the differences range from more than 40 percentage points in Denmark to 5 percentage points or less in Chile, Israel and Japan.

In some countries, vocational systems are flexible enough to allow students who left the education system early to re-enter later on.

On average, the age at graduation is higher for vocational graduates (22 years old) than for graduates of general programmes (19 years old). However, in Belgium, Brazil, Denmark, Finland, Iceland, Ireland, the Netherlands and Norway, the average age of graduates from vocational programmes is 25 or older; in Australia, it reaches 31. One reason for these differences is that, in many education systems, VET provides a second chance by enabling some to reintegrate into a learning environment, developing skills that will thereafter increase their employability. For example, the Australian VET system is flexible and able to satisfy different needs at different stages of people's lives, whether they are preparing for a first career, seeking additional skills to assist in their work or catching up on educational attainment. This difference in the age of graduation is also partially explained by the fact that VET programmes also tend to cater for students with greater difficulties who also graduate from earlier levels of education at a later age.

\section{Having a strong work-based learning component integrated intoVET programmes can act as a guarantee of excellence.}

In some systems, school-based learning is widely combined with work-based learning. Examples of this type of

"dual system" can be found in Austria, the Czech Republic, Denmark, Germany, Hungary, the Netherlands, the

Slovak Republic and Switzerland (Figure 1). Through work-based learning, students acquire the skills that are valued in the workplace. Work-based learning is also a way to develop public-private partnerships and to allow social partners and employers to get involved in the development of VET programmes, often including the definition of curricular frameworks.

As a result, VET with a well-integrated work-based learning component can ease transitions between school and work. However, less than 30\% of students enrolled in upper secondary VET programmes are exposed to work-based learning on average across OECD countries.

\section{Good connections between education programmes offer students better opportunities to continue their education.}

Although some countries have made substantial progress in linking VET to other parts of the education system, on average, less than $15 \%$ of young people who graduate from upper secondary vocational tracks continue into post-secondary education (Figure 2). In some countries, this is because students find jobs after completing upper secondary VET. However, in other contexts, this is due to the fact that students from upper secondary VET face difficulties in continuing their education. 
Figure 2. Transition from upper secondary vocational education and training to post-secondary education

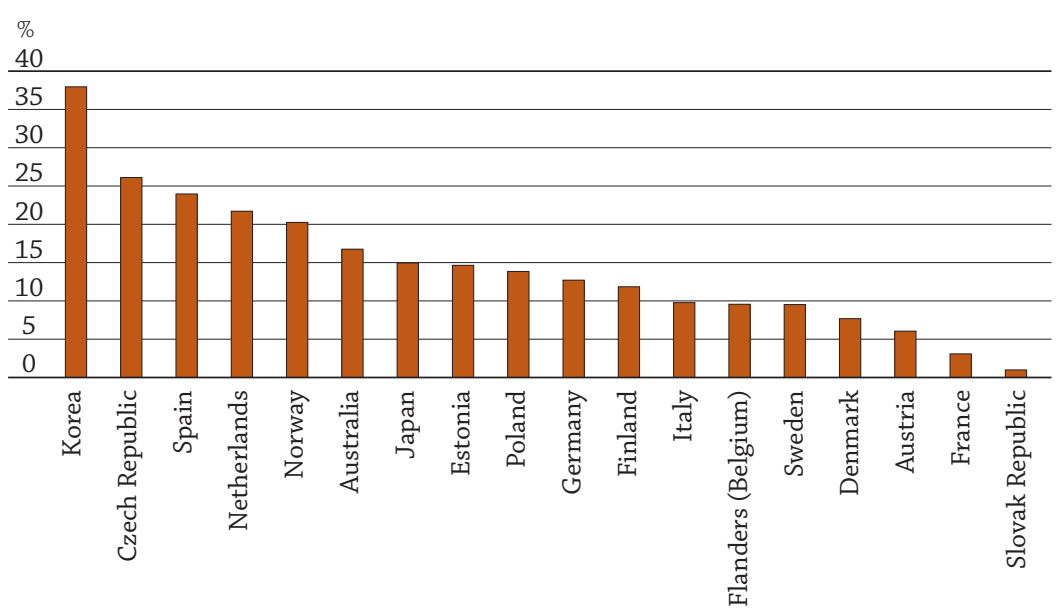

Source: OECD (2015a), OECD Skills Outlook 2015: Youth, Skills and Employability, Figure 2.11, http://dx.doi.org/10.1787/9789264234178-en.

On average, upper secondary VET graduates are nearly five times less likely to enrol in further education than graduates from general secondary schools with similar proficiency in literacy. However, some OECD countries have made efforts to diversify the routes through education. For example, in Switzerland, dual diplomas combining a VET qualification with a university entrance qualification facilitate access to higher education. In Germany, access to university for VET graduates was formally enhanced in 2009 and is strongly supported by government campaigns. Lastly, in the Netherlands, the different learning routes - including vocational programmes - are structured in such a way that young people have the possibility to progress within the track they have chosen, and reach the equivalent of tertiary level education.

Nevertheless, improving the quality of VET will be crucial to combatting its negative image in many other countries and to create opportunities for further education. Students in VET programmes have relatively low cognitive skills. In many OECD countries, upper secondary VET students are 50\% more likely to have poor numeracy skills than students in general programmes of a similar education level. The gap in earnings between post-secondary and tertiary VET versus academic general graduates may also partly explain the preference of the best students for academic pathways. This gap is particularly large in countries where the training associated with vocational programmes is of poor quality and badly monitored.

\section{High-qualityVET programmes can strengthen youth employability.}

High-quality VET programmes tend to be effective in developing skills among those who would otherwise lack qualifications to ensure a smooth and successful transition into the labour market. It is important for the graduates of upper secondary VET programmes to have good employment opportunities because VET can be a costly endeavour once you include the costs of instructors and facilities. This explains why the average annual expenditure per student enrolled in an upper secondary VET programme is significantly higher than the same expenditure per student enrolled in a general programme.

Across OECD countries for which data are available, $78 \%$ of $25-34$ year-olds with at most a vocational upper secondary or post-secondary non-tertiary qualification are employed - a rate that is 11 percentage points higher than that among individuals with only general upper secondary education (Figure 3). Moreover, countries with strong VET systems have been relatively successful in maintaining stable employment rates for young people throughout the crisis. 


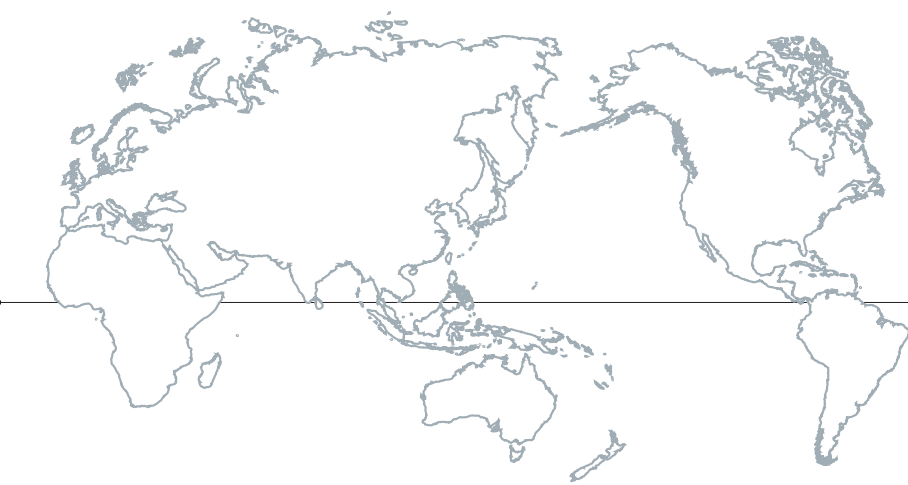

Figure 3. Employment rates among adults with upper secondary education as highest level of education attained, by type of programme (2013)

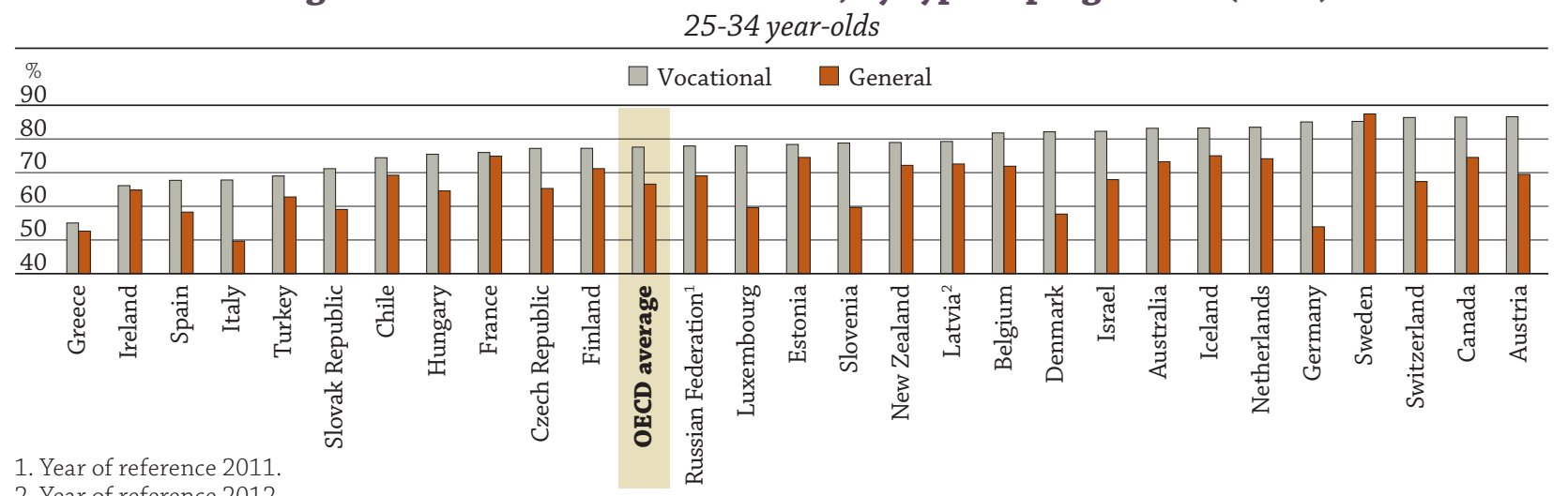

2. Year of reference 2012

Countries are ranked in ascending order of the proportion of employed adults with an upper secondary education with vocational orientation as highest level of educational attainment.

Source: OECD (2015b), Education at a Glance Interim Report, Table 2.5. See Annex for notes (www.oecd.org/edu/eag.htm).

Yet, despite the employment advantage of an upper secondary vocational qualification in most countries, the proportion of upper secondary VET graduates who are neither employed, nor in education or training (NEET) is larger than the proportion of graduates from upper secondary general programmes. This is partly because students in general programmes are more likely to continue education after they graduate from secondary school.

The bottom line: An increasing number of countries are recognising that good initial vocational education and training has a major contribution to make to economic competitiveness. At upper secondary level, VET is more strongly correlated to employability than general education, especially when policy makers succeed in aligning the skills obtained in the programmes with those demanded by the labour market. Nevertheless, improving the quality of VET is crucial to combatting the negative image of VET in many countries and to creating opportunities for further education. To achieve this, social partners can engage with the various levels of the VET system, from secondary to higher education, to develop work-based learning and to provide flexible modes of study suitable for adults with working and home commitments.

\section{For more information}

OECD (2015a), OECD Skills Outlook 2015: Youth, Skills and Employability, OECD Publishing, Paris.

OECD (2015b), Education at a Glance Interim Report: Update of Employment and Educational Attainment Indicators, OECD, Paris.

OECD (2014), Education at a Glance 2014: OECD Indicators, OECD Publishing, Paris.

OECD (2013), “Does Upper Secondary Vocational Education and Training Improve the Prospects of Young Adults?", Education Indicators in Focus, No. 17, OECD Publishing, Paris.

OECD (2010), Learning for Jobs, OECD Reviews of Vocational Education and Training, OECD Publishing, Paris.

\section{Contact}

Diogo Amaro de Paula (Diogo.Amaro@oecd.org) / Éric Charbonnier (Eric.Charbonnier@oecd.org) / Margarita Kalamova (Margarita.Kalamova@oecd.org)

\begin{tabular}{l|l}
\hline $\begin{array}{l}\text { Visit } \\
\text { www.oecd.org/edu/eag.htm }\end{array}$ & $\begin{array}{l}\text { Coming next month } \\
\text { What are the labour market opportunities for upper secondary graduates? }\end{array}$ \\
\hline Adult Skills in Focus & \\
\hline Education Indicators in Focus (previous issues) & \\
\hline PISA in Focus & \\
\hline Teaching in Focus & \\
\hline
\end{tabular}

Photo credit: @ Ghislain \& Marie David de Lossy/Cultura/Getty Images

This paper is published under the responsibility of the Secretary-General of the OECD. The opinions expressed and arguments employed herein do not necessarily reflect the official views of OECD member countries.

This document and any map included herein are without prejudice to the status of or sovereignty over any territory, to the delimitation of international frontiers and boundaries and to the name of any territory, city or area.

The statistical data for Israel are supplied by and under the responsibility of the relevant Israeli authorities. The use of such data by the OECD is without prejudice to the status of the Golan Heights, East Jerusalem and Israeli settlements in the West Bank under the terms of international law. 